\title{
ANALYSIS OF ONLINE MODELS IN THE INDEPENDENT CAMPUS
}

\author{
Agus Iwan Mulyanto, ai_mulyanto@unis.ac.id ${ }^{1}$ \\ Aggih Perian Guswan Putra, anggih.pgp@ gmail.com ${ }^{2}$ \\ Chairiel Oktaviar, chairiel.oktaviar@mercubuana.ac.id ${ }^{3}$ \\ Erialdy, erialdy@unis.ac.id ${ }^{4}$ \\ ${ }^{3}$ Universitas Mercu Buana
}

\begin{abstract}
Rapid response When the Minister of Education and Culture issued Circular Letter No. 3 of 2020 concerning the Prevention of Covid-19 must be taken to take effective prevention and mitigation measures for the outbreak that has now become a global pandemic. This article analyzes the implementation of online learning in the era of independent learning and independent campus under COVID-19 conditions. With library research methods that refer to resources available online, this article presents a perspective of service activist learning about strategies to deal with conditions that are difficult to predict. From the results of theoretical analysis, there is no uniformity of understanding of information about the characteristics of the plague in the government as a regulator, discussing the understanding of the main definitions related to the problem of online learning with the perspective of independent learning and independent campuses. The choice that most allows lecturers in 'free teaching' so that they focus more on efforts to transfer knowledge and skills to students. The policy can also encourage students to be more innovative and creative in learning (student-centered learning) is online. The physical encounter will not be abandoned even though advances in virtual and digital technology have thickened. Although the COVID-19 outbreak will last a long time, there is no harm in having to think about patterns and methods of physical and social learning that are safe for everyone. The development of communication and digital technology has a significant role that can be utilized as widely as possible by academia to look brighter future.
\end{abstract}

Keywords: Dolanan, Covid-19, Merdeka Campus, Online.

\section{A. Introduction}

The impact of the Covid-19 pandemic in the world of education has been recognized by UNESCO's educational organizations. Nearly 300 million students disrupted their school activities around the world and threatened them in the future. The most feared impact is a long-term effect. Because students will automatically feel the delay in the ongoing education process. This can lead to late growth in their maturity in the future. Especially if Covid-19 does not end soon.

School delay policies in countries affected by the virus can automatically disrupt the right of every citizen to get proper education services. The central government until the regional government issued a policy to dismiss all educational institutions. This was done as an effort to prevent the spread of the Corona Virus (Covid-19). Until now in Indonesia, several schools up to the campus, both private and public, have begun implementing policies for distance learning activities or online-based learning by utilizing existing online learning applications such as the Edmodo application, Google classroom, zoom, and so on.

But the irony is so far whether there has ever been a question in how big the impact of Covid-19 on education in Indonesia? Effective steps to learn from home that has been running so far? How is the key to online learning success during the Covid-19 outbreak? This is what makes our world of education change 180 degrees. Because the only solution that can be offered by doing online learning (online classroom). This is like providing shock therapy for lecturers and students.

Many lecturers are not yet familiar with online learning and how to do it, as well as students who are not yet familiar 
with online learning. The government decided to cancel the National Examination, an effort to suppress the spread of Covid-19 since the government decided that its students learn from home. Online learning or online learning is distance learning that can answer the wishes of the government and the community so that the teaching and learning process continues to run well using a computer or gadget where lecturers and students communicate interactively by utilizing communication and information media. This learning is very dependent on the internet network connection that connects lecturers and students.

The constraint when online learning is a habitual pattern of teaching and learning for students and lecturers who are accustomed to conventional learning. Lecturers are still not accustomed to teaching by utilizing complex online media which must be packaged effectively, easily accessed and understood by students. While students need a culture of independent learning and the habit of learning to follow a computer or gadget. Lecturers are required to be able to design or design lightweight and effective online learning, by utilizing appropriate online devices or media and by the material taught. Online learning will provide wider opportunities to describe what will be taught. Lecturers must be able to choose and limit the extent of the scope of the material and what applications are suitable for the material and learning methods used.

In the process, this modern online learning model has been regulated by Minister of Education and Culture No. 22 of 2016 concerning the standard process with the following principles, from students being told to learners to find out. From lecturers as the only source of learning to learn based on various learning resources. From the textual approach to the process as a reinforcement of the use of scientific approaches. From partial learning to integrated learning. From learning that emphasizes single answers to learning with answers that are multidimensional truth. From learning verbalism to applicative skills. Improvement and balance between physical skills (hard skills) and mental skills (soft skills). Learning that prioritizes the culture and empowerment of students as lifelong learners. Learning that applies values with exemplary material (ing ngarso sung tulado), the building will (ing madyo mangun karso) and developing students' creativity in the learning process (tut wuri handayani).

Learning that takes place at home at school and in the community. Learning that applies the principle that anyone is a lecturer, anyone is a student, anywhere is the class. Utilization of information and communication technology to improve the efficiency and effectiveness of learning. Recognition of individual differences and cultural backgrounds of students. The key to successful online learning during the Covid-19 pandemic is to choose an application that suits the needs of lecturers and students. For example Whatsapp Group. This application is suitable for beginner online teachers because the operation is very simple and easily accessible to students. Examples of activities, for example, lecturers give assignments to students by giving colouring video tutorials via WhatsApp.

A series of strategies must be carried out by a lecturer to address the learning situation during New Normal where the existence of the COVID 19 outbreak is still until further notice (UFN) so play with students, suggested by our Father of National Education, the curriculum designed by Dewantara (1945) is delivered by playing (dolanan/games) such as child playing and games, dance, gamelan music, etc. to be a solution because it can be done in an open and spacious room, which are delivered with various games, about how to play thus highlighting the instrumental and epistemological dimensions of the game as 
a means to achieve learning objectives namely the progress of children's soft skills. The view of the leading German philosopher, Hans-Georg Gadamer (19022002), the concept of "play" (spiel) has a deep ontological weight, not only instrumentalist but epistemological as stated.

Gadamer (1960) in, Truth and Method discuss the importance of playing in revealing the truth that manifests in the ontological structure of art and human experience about art itself. "Playing" with "serious" Playing is, in its insight, mistaken if understood as mere play. "If playing is only understood as playing, it is not serious. Playing has a special relationship with seriousness. It is the seriousness that gives 'purpose' to play, as Aristotle said, we play 'for recreation'.

Joy factor is a tool for lecturers or lecturers to improve learning achievement, that is the most important word in the world of education. Hopefully, we can remember the concept of learning, Indonesian education leaders on this birthday. The concept of learning while playing that gives birth to the excitement. Hopefully, we can recall the concept of learning from Dewantara (1945), owner of the full name Raden Mas Soewardi Soerjaningrat who advocated teaching children to play to create a happy atmosphere. But, as we all know, the excitement seems to have vanished with online learning as a result of the Covid-19 pandemic.

How can learning goals be achieved if the excitement is no longer theirs? Joy as a learning strategy in the world of education is a learning strategy that must be placed first. If, a myriad of problems have been complained by students' parents, even, the Commission Indonesian Child Protection (KPAI, 2020) says it has received hundreds of complaints from various regions in Indonesia. National Education Day 2020, is a moment of millennial lecturers amid the Covid-19 outbreak, several students complained about the heavy assignment of lecturers which had to be done with a tight deadline. Meanwhile, on the other hand, the tasks of other lecturers have been waiting for, although not exposed, the lecturer might complain of running out of style to perform in front of their students online.

Playing has a special relationship with seriousness. It is the seriousness that gives 'purpose' to play, as Aristotle said, we play 'for recreation'. Gadamer (1960) in, Truth and Method also discuss the importance of playing in revealing the truth that manifests in the ontological structure of art and human experience about art itself. "Playing" with "serious" Playing is, in its insight, mistaken if understood as mere play. "If playing is only understood as playing, it is not serious. A series of strategies must be carried out by a lecturer. Play with students, suggested by our Father of National Education. curriculum was delivered by playing (games) such as child playing the games, dance, gamelan music, etc.

Playing fulfils its purpose only if the player loses himself in playing. Seriousness is not something that keeps us from playing; but instead, the seriousness in playing is a necessary thing to make playing real. (Gadamer, 1989: in Putranto, 2010: 59). Playing one of the entertaining methods is a form of creative effort in developing the quality of learning of any subject, Tourism Management for example. Many interesting challenges and make us have a new spirit when entering the world of Tourism Management. With the challenges for the sake of that challenge, the idea of creativity also emerged, one of which was the application of the amusement method. According to Makarim (2020) in a speech (Hardiknas, 2020), it was not only this goal that made playing serious. Playing on itself contains seriousness, even seriousness that is sacred. In the play, all purposeful relationships that determine active and 
caring existence thereof are postponed, not disappeared.

\section{A. Methodology}

This article uses the method of library research conducted by referring to journal articles, repositories, mass media coverage, social media and all resources that can be accessed online. These sources are collected based on discussion and examined one by one and linked between one information with other information. All data collection and analysis activities are carried out online given the limitations of open movement in public spaces. Data obtained by categorizing the problem referring to the sources available for analysis than using triangulation techniques with theory, in this case, the sociology theory of mass communication and theory in public life.

\section{B. Discussion}

It is like when we just came out of the cinema door after watching a movie, there is an impression left in our soul, there is a moral message that can change and purify our souls into a better figure, however temporary it is. With the entertaining method, after leaving the classroom door or leaving the online forum/class, learners will have new knowledge and experiences that are memorable about self-awareness to care, love, and be proud of Tourism Management. When referring to a book by Timothy D. Walker, Teach like Finland; 1). a lecturer who inspires and excites his students must offer a choice. Before independent learning (when learning in the middle of the Covid-19 pandemic) begins, a lecturer should offer choices in the form of assignments that are tailored to the interests of students. The independent learning "Merdeka Belajar" Program If it is linked to the Makarim (2019) Idea independent Learning Program; this is a free choice that can be given to students to suit their interests and character. Remember, the lecturer's task is not only to run the curriculum but also to be a link between the curriculum and student interests. Some teachers apply conservative teaching methods. They give step-by-step instructions so that students are like being bribed with a spoon. In fact, everyone has a different way of learning.

The entertaining method of learning why is it important to apply the amusement method to Tourism Management learning? Reason: 1). Tourism Management is often underestimated by others so that it becomes a less attractive subject. In addition to conventional materials and conventional methods, less creative teachers create attractive teaching styles that make Tourism Management less wellliked. The entertaining method is here to answer the problem. Everyone without exception likes entertainment. With the entertaining method, Tourism Management learning becomes interesting learning; 2), with the entertaining method without the learner feeling already learning independently and effectively. Without us being forced to learn, naturally, they have learned. Tourism Management learning will be fun, relaxed but serious, serious but relaxed learning, as Gadamer has summarized; 3). good teaching and learning is a process that puts learners at the centre of learning. In the language of curriculum and pedagogy, this is known as student-centred learning (Barr and Tagg, 1995), do this for the sake of eastern Indonesia students the task of teaching staff: motivating and facilitating teaching assignments as motivators and facilitators. Through the method of entertaining learners without being actively involved, eager to learn, and become a centre of learning in the middle of a series of teaching and learning processes. The task of teaching is to direct learners to stay in the corridor of learning achievements; 4). the entertaining method is important for Tourism Management learning because of the catharsis process which is widely understood as a process of purification and refreshment. 
Gardner (2005) explains this
through the theory of multiple intelligences. Most people cannot optimally follow various intelligence taught in educational institutions (including verbal/linguistic skills and logic/mathematics; 2). make plans with students. Involve our students when we plan the learning to be done. Planning the direction and learning process is not solely the responsibility of lecturers, but also students (and also known by parents). Thus, through this joint planning can be at the same time a place to develop the potential or talents of students; 3 ). utilizing technology. During this Large-Scale Social Restriction (PSBB), several online teaching applications can be used such as Google Classroom, Microsoft Team, and Zoom Meeting. The key to the success of learning by using this technology is in the hands of a lecturer.

Edunex Learning Management System (LMS) to support online lectures, therefore, a lecturer, without reason of being bored, must still be able to run technology as a means of learning achievement, able to support learning that can bring excitement to lecturers and students, especially when technology makes we do what educator Will Richarson calls "extraordinary things". Fourth, discuss values. For some lecturers, giving grades is a "prerogative" right. In fact, for some students, values are related to self-esteem. It would be more encouraging if grades could be discussed between lecturers and students. This gives freedom to students to make their own choices based on students' interests and character. Through personal discussion, we can provide support and better understanding of the achievement of learning objectives. "Star system": hopes, ideals and achievements.

The star system becomes an evaluation tool in the learning process with an asterisk as a sign that the goal has been achieved, where a beautiful celestial body has its light, hopes, ideals, something to be achieved, a star is an achievement and a star is a gift. Asterisks are markers of the success of a person or institution's performance. The best hotel is a five-star hotel. Even the best flight uses a 5-star standard. "Don't forget to give a star, Ma'am!" begged the driver online to his passengers hoping to give him 5 stars as a sign that he had provided the best service. Likewise in the world of education. Stars become a mark of the success of students in achieving their goals. Students with 5 stars are markers of their achievements. With a star system, students act as educational subjects. One example of a learning method with challenging evaluations and rules of the play whose values can be discussed with students is an assessment system called the "Star System".

This method is very interactive, inspiring, fun, challenging, and motivates students to learn from their own hearts, not because of coercion. Learning according to students' "styles" With the game, students are able to follow the material by learning that is spatially, kinesthetic, musical, interpersonal, naturalistic, and intrapersonal.

When students have the opportunity to learn according to their own style, they become more able to master the subject. The most important advantage of making games is to make students interact, follow rules, take turns, correct each other, and compete with one another. This helps students to develop their thinking, problem solving, hearing, and verbal abilities. This relaxed and competitive and motivational situation makes students have to use their imagination and creativity to remember the subject, also requires them to remember past memories to be connected with the subject. Not because of fear of punishment, assessment methods like this make students feel challenged and excited about learning and generate excitement if students are able. At the beginning of the meeting, it was explained that during the 14 meetings a quiz would be given. The 
quiz can be in the form of games and student training in the classroom, assignments in the lecture hall, off-campus assignments, or assignments at home during the PSBB.

The challenges of this evaluation, do not stop here. if able to achieve the National target. Each task will be carefully corrected, both by the lecturer and carried out by students together as meeting the requirements.

This has an impact on improving the quality of student learning outcomes in order to understand their goals from the start and try to achieve them with motivation that comes from themselves. In addition, students must compete with each other to meet these requirements so that they are motivated by the competitive nuances that emerge. Failure in one of the three conditions will make a student lose the grand prize automatically. When a student is able to get a grand prize, the student's competency has been objectively tested from the independent requirements.

Grades also show good results and student attendance shows more attendance than attendance at courses taught by other lecturers. They were right in the classroom not because they had to obey the rules or fear punishment, but because they started to love the Tourism Management course. They are very disadvantaged if they are late or not in the Tourism Management course. Being late means that the loss does not witness the lecturers' performances in the first 15 minutes, not going to college means the chance to get a star is missed. Homo ludens may be some people think that the entertaining method only belongs to students or elementary schools. However, remember that humans are homo ludens, God's creatures who like to play. Anyone regardless of age, including students. Indeed, the learning process at the high level of lecturing has often been associated with seriousness, business independence, and methodological rigor. However, in reality, especially for Tourism Management courses which are in fact rarely interested by students, when this entertaining method is applied at a high level of lecturing, the excitement and emergence of Tourism Management learning enthusiasm increases.

To provide learning that will arouse motivation for students is done by combining theories and models of Rosa Maria learning that exemplifies by giving motivation to learning in the classroom that is motivation To provide learning that will arouse motivation for students is done by combining theories and learning models that exemplify by motivating learning in the classroom, namely intrinsic motivation and extrinsic motivation. Intrinsic motivation is tied to the needs of intervals such as self-satisfaction in making a task, while extrinsic motivation is related to the acquisition of rewards such as values and gifts (Tomlinson, 1987: 239). The asterisk in this challenging evaluation is a form of prize that will be received by students who can complete learning achievements by the interests and character of students. Boring, tedious, burdensome, forced, overly theoretical, conservative methods, full of assignments, full of complaints, many theories, inadequate lecturers, lecture methods, and never practised are negative predicates of Tourism Management learning. This time was obtained based on observations of student interest in the Tourism Management course before attending the Tourism Management lecture by applying the entertaining method.

This further strengthens the initial suspicion that Tourism Management learning is something that does not excite students. After they joined Tourism Management lectures with entertaining and exciting methods, the negative predicate turned into something positive. Enthusiastic at every meeting, the spirit of competition, active, more challenged, a lot of inspiration, fun, self-awareness to care, love, and proud of Tourism Management, motivated to be more serious in learning, hone the ability to respond quickly, train cooperation, foster competitiveness that is 
positive, more sensitive to mistakes, more critical, exciting, entertaining, full of creativity, fun, very effective, interactive, attractive, innovative, and makes Tourism Management a classy subject. The amusement method in the form of a game is not just a play that is not directed and has no value, but rather through a game, the seriousness of students to explore and understand teaching materials will be tested, both at the level of ethos, logos and pathos.

Through the entertaining method, students will still be intrigued and excited to care for the spirit of learning despite being in the midst of the Covid-19 pandemic. Through the entertaining method, on this National Education day, let us become the relay holder to continue the noble ideas of the lecturer, Ki Hadjar Dewantara by continuing to be an inspirational and exciting scholar for the nation's children.

The view of teaching as an interaction between actors of learning will be offered in building a distance learning system. The COVID-19 outbreak has caused a variety of panic, including in the realm of higher education. Especially after the central government has reacted successively with various actions such as establishing alert status, disaster emergencies, non-natural disasters, the extension of disaster emergency status to Large-Scale Social Restrictions (PSBB). Since then COVID-19 prevention measures have been implemented in the form of social \& physical distancing in various lines of life. This policy is based on the number of victims who continue to grow and the distribution of the virus is increasingly difficult to control throughout Indonesia.

Through the Minister of Education and Culture Circular Letter No. 3 of 2020 concerning Prevention of COVID-19 in the Education unit, all higher education in Indonesia is no exception even private universities take a decisive step on the government's call for learning activities at home. All academic activities that are normally carried out on campus, during this pandemic period must be done from home. Not only students, lecturers and students (education personnel) were forced to work from home to prevent and accelerate the decline in the COVID-19 outbreak. Policies and pandemic phenomena whose effects are extraordinary and occur so quickly have forced the world of higher education to change the work pattern of services from conventional to online-based services.

One of the pilot tertiary education institutions in Indonesia that had applied the blended learning system technology before the COVID-19 outbreak was University in Tangerang. Naturally, if the government policy that requested all teaching and learning activities carried out at home during the Covid-19 pandemic was not so surprising for all university. That's because the technology infrastructure and its human resources have been prepared even though the learning system that has not been applied 100 percent online.

Blended learning or called hybrid courses is a learning process that combines online learning and face-to-face between lecturers and students. During the COVID19 disaster emergency, UBSI applies a full online learning method for all courses by utilizing the Learning Management System (LMS), students can access lecture material, discussion boards through discussion forums, chatrooms, and access lecture assignments given by lecturers.

Lecturers are also encouraged to be more creative in providing online learning material, namely by creating learning videos in the form of tutorials uploaded on Youtube, maximizing the use of Google Classroom, WhatsAap Group and video conferencing applications such as Zoom, Skype, Hangouts and Webex. The key to all of that is communication, where the lecturer must continue to pay attention to the development of their students namely by ensuring the right to education 
continues to run even with technology intermediaries.

It is undeniable that the use of technology from online learning systems during the COVID-19 pandemic certainly has both positive and negative sides. The positive side of online learning is one of which opens the freedom of expression of student ideas that do not appear during face-to-face lectures because of shame, reluctance, fear or even do not have good verbal skills. In addition, online learning can also help students who live in remote areas who have difficulty accessing campus and time clashes, especially students who study while working.

In addition, it eliminates 'top and down' traditional teaching patterns in which the lecturer knows everything and students are only required to follow what the lecturer says. Also, increasing creativity and independence, both lecturers and students, in enriching themselves by continuing to innovate to always look for new knowledge.

While the negative side of the online learning system is that not all students have the same level of understanding. For students who are diligent and easy absorb information than the way online learning will be easily absorbed, but for those who are unfamiliar with that method, it is likely to be difficult not only to absorb the lecture-based online delivered by lecturers but also the ability to adapt to the application of technology used in Teaching and Learning Activities.

Facts on the ground, the obligation to study at home is a serious obstacle especially for students from economically disadvantaged groups. They often complain about the end of internet quota packages. Also, technology can build an instant attitude from its users.

Lecturers and students can be easily spoiled by copying and pasting learning material or assignments. However, the gradual disappearance of physical encounters due to lectures delivered online will have an impact on the loss of humanity such as empathy and caring. It is common sense and accepted by common sense if someone says the presence of an educator or lecturer in front of the class will not be replaced by technology.

Seeing the portrait of the world of education in the midst of this pandemic COVID-19 is ready or not, has opened the eyes of the public especially higher education to work hard, think creatively and adaptively by changing the model of teaching and learning activities that were originally based on conventional learning into e-learning based. This COVID-19 pandemic is a momentum for the world of education to make breakthroughs, out of the normative paradigm of the real world into cyberspace by utilizing technology in every Teaching and Learning Process Activity (KBM) and other non-academic services.

Educational institutions that still survive with the traditional learning model may be left behind by the community, swept away by the storm of this very virulent COVID-19 virus. We all hope that the disaster will soon pass and educational activities and other sectors can soon recover.

Many schools and tertiary institutions were closed, due to the COVID-19 pandemic, as in UNICEF's account of nearly 300 million students affected by the closure of the educational institution. Several regions in Indonesia, have also been prepared to face COVID19 by closing these schools. Several higher education institutions in Indonesia also carried out a similar policy, whereby this policy, which aims to prevent the spread of COVID-19 infection, is in line with WHO's call that all elements of society need to participate in preventing and minimizing the impact of the disease, the policy does not dampen educational institutions This is to conduct learning, not face-to-face learning but Long Distance Learning (LDL). 
No doubt, the transition of modes of learning from face to face (and maybe some have already applied blended learning) to distance learning will raise many questions. One of the many questions might be like this, "What is the design of effective distance learning?" This question will be the focus of this article's discussion. So that the discussion is in line with the independence learning program launched by the Ministry of Education and Culture of the Republic of Indonesia, then the discussion will be packaged as an action from the call to action program. Therefore, a brief explanation of the idea of independent learning will be reviewed as follows.

When I first heard the term ' independent of learning program', I was sceptical. These goals are too ambitious to be carried out given the very diverse conditions of national education. Then I reflected and finally asked myself, "Isn't there an ambitious educational program needed, so students (who are indeed worthy and need to receive the highest quality education) can prepare for the future in this changing world?" Perhaps from this kind of thinking finally the spirit of innovation and learning culture became the spirit of an independent learning program to create students who have a growth mindset.

Isn't it necessary that an ambitious education program so that students can prepare for the future in this changing world, the spirit to innovate is thus to become a spirit: 1). independent learning program. With this enthusiasm, educators are required to explore and apply various kinds of theories, approaches and principles of learning design to create an innovative learning environment for their students. Therefore, educators need to reflect continuously on their teaching practices and apply and develop the latest learning models, such as flipped classroom, blended learning, and online learning. Educators need to optimize the devices that are owned by students, or that have been provided for them, to create innovative, active, and in-depth learning; $2)$. the independent learning program is a culture of learning, in providing quality learning for students, educators are required to always learn from and with other educators. Furthermore, educators must also not be afraid to explore and experiment with learning methods that are promising and have proven their effectiveness as efforts to improve their teaching practices. To realize this learning culture, educators need to be actively involved in the networking of their profession, both locally and globally, and always update their knowledge related to research results in the field of education.

The two spirits of independent learning above basically reminding educators of the spirit of dedication, namely the spirit of innovation and continuous learning to prepare their students for their future. It is this spirit of innovation and learning that must be held in designing and facilitating learning for students, not least for distance learning. Distance learning design, learning distance needs to be carefully designed to facilitate optimal student learning. Many teaching design principles are available in the literature to do so. Here I will offer the principle of 'teaching as interaction' as a framework for designing distance learning. This principle recognizes that teaching involves a complex process between actors of learning so that the actors of learning are interdependent with each other. Because, this principle can provide an overview of interactions between learning actors that occur in distance learning, which provides opportunities for modern learning approaches that require interaction between learners in an online learning environment, for example, computer-assisted or computer-supported collaborative learning (CSCL).

The principle of teaching as interaction has the axiom that teaching is the interaction between educators and students around learning content, this 
principle interprets teaching as what educators do, say, and think together with their students about learning content in a learning environment. This principle is illustrated in Figure 1. Therefore, to design effective distance learning, various strategies need to be thought out and designed to facilitate interaction between educators and learning content, students with learning content, students with educators, and students with other students.

Figure 1 Teaching as interaction.

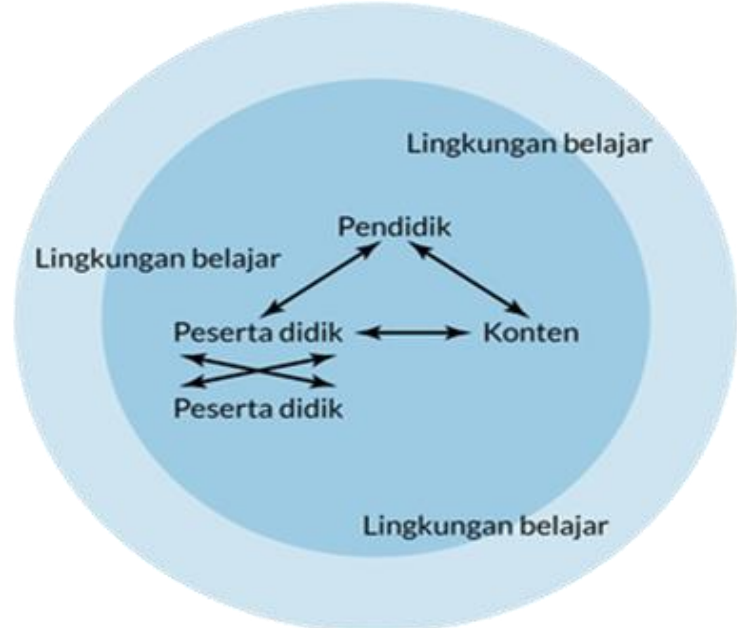

Educators and learning content, the first role of educators in organizing distance learning is developing learning content. To do this, educators, of course, must think that the learning content will be delivered online. This assumption is crucial in developing content for distance learning. Then, educators also need to determine the components of the learning content, consider and pay attention to existing learning content, and finally develop it.

As mentioned earlier, the assumption that the learning content is delivered online is important in developing content for distance learning. With this assumption, educators must be aware that the purpose of distance learning is to replace the face-to-face learning experience in the classroom. Also, in contrast to face-to-face learning, educator facilitation to students will be centred on online software and applications. Students in this learning system are also assumed to be independent or not too dependent on the direct assistance of educators.

The result is that this choice must be taken to take effective preventative and mitigating actions for outbreaks that have now become a global pandemic. Among the policies taken are deactivating lecture activities in the campus environment to carry out sterilization and to carry out independent quarantine of students, lecturers, and education staff, including not conducting public meetings at the same time turning on lectures and thesis guidance online. The policy is active from March to December 2020 and even then it can not be predicted when this outbreak will end, only the discipline of the whole community and is no exception. Of course, there are difficulties when this new policy is implemented. It was also explained that terminating face-to-face directly does not mean that lectures and guidance are not conducted.

However, with the conventional lecture tradition, the choice of conducting online learning from each residence is not easy to do. Bearing in mind: 1). requires device readiness and of course internet data packages that are still managed independently; 2). not all lecturers and students are ready to operate the online learning system quickly, including preparing digital lecture material. Learning from outside the campus is certainly part of what Makarim (2020) has mandated, to realize Independent Learning and Campus. Indeed, if viewed from its objectives, regulation concerning National Standards for Higher Education is more focused on changing the system of campus accreditation and bureaucratization. That choice allows 'independent teaching' lecturers to focus more on efforts to transfer knowledge and skills to students. The policy can also encourage students to be more innovative and creative in learning (student centered learning). Creative amid the accident of the 19th plague, the plague has indeed become a 
global concern. This outbreak has caused lethargy in various sectors: financial, trade, tourism, socio-cultural, and also economic growth. However, it is inappropriate for us to be stuck in a global meltdown. Many initiatives can be done to stay in the middle of difficulties. In the world of education, including tertiary education, can utilize the freedom of thought to escape from problems and look to the future with optimism.

One of the things that can be done by higher education is to 'lockdown' physical lectures - of course temporary and maximize 'open up' lectures of other models by utilizing virtual and digital technology. The industrial revolution 4.0 enables us to carry out renewable initiatives to maximize the functions of communication, information transfer, and knowledge. The world may plague and be squeezed by slowing growth, but the world of education must keep running for the sake of continuing civilization. Indeed, physical encounters cannot be sidelined. For moments like graduation, graduation, Field Work Practice (PKL), also Real Work Lectures (KKN), and of course 'traditional' lectures, real and social encounters must be held. That is because the purpose of higher education as stated in Law No. 12 of 2012 applying the value of humanities and civilization to shape Indonesian people of character must be done in the real world. The physical encounter will not be abandoned even though advances in virtual and digital technology have thickened. Although the COVID-19 outbreak will last a long time, we must think of patterns and methods of physical and social learning that are safe for everyone. The development of communication and digital technology has a significant role that can be utilized as widely as possible by academia to look brighter future.

Prevention of Covid-19 in the Education Unit in anticipation of the spread of Coronavirus in various schools and high schools, and also pay attention to the Determination of the Status of Extraordinary Events with the Status of the Specific Emergency Disasters Due to Corona Virus Disease 2019 (Covid-19) following up on the Government's recommendations As well as referring to the Circular Letter on Lockdown for Preventing the Spread of Corona Virus Infection (Covid-19), the implementation of academic activities in the emergency period of the spread of COVID 19 on Campus eliminates face-to-face learning activities and replaces them by Working From Home (WFH) and Learning From Home (LFH) through online learning with a variety of media.

This is done to prevent and avoid the spread of the Corona Covid-19 virus that is currently spreading in several countries, including in Indonesia. Working from home (WFH) and Learning from home (LFH), not gathering and keeping a distance are considered the best ways to break the chain of the spread of this virus.

However, online learning is not fully welcomed by students, because some students find online learning more difficult than ordinary learning, not to mention the internet quota must be available and this is the biggest difficulty experienced by students, constraints on the network, the availability of learning tools such as laptops, the level of understanding of the material are felt better when conducting face-to-face lectures, and also not all lecturers and students are ready to operate the online learning system quickly, including preparing digital lecture material.

Academic explained that online lectures during the Covid-19 pandemic were the most appropriate way to carry out the learning process for students. Online lecture activities can be done through various learning applications such as WA Group, Google Classroom, Zoom, Google Meet, etc., although it was realized that the results achieved will not be as maximal if the process is carried out face-to-face on campus, therefore it is necessary for 
controlling by the study program through online learning guidelines mechanism that has been issued and is expected to run well he said. It was further explained that planning to carry out online learning until May and subsequently for practicum activities will be held in June and July while the final semester exams which will certainly also be held will be held in early August in the hope that this disaster will end soon so can carry out the lecture process again normally.

Learning Solutions in the era are spreading, online lectures provide distance learning where lecture materials provided through technology tools will certainly make it easier for students to continue to get lectures without face to face, Hamka (1981) again said this choice must be taken to take preventative and mitigating actions that effective over the epidemic which has now become a global pandemic, among the policies taken is to deactivate lecture activities in the campus environment and to carry out independent quarantine of students, lecturers, and education staff, other employees and including not conducting meetings but conducting lectures and online guidance, even though online learning only provides theoretical abilities, so the Higher Education itself is still far away from obtaining the skills or competencies that must be obtained if it practices with face-to-face models. In the COVID pandemic era 19, the quality of learning in all lectures is certainly high including, because normal learning theory and practice should be in line with the means of pursuing theory and direct practice, but even so at least this online process helps the implementation of lectures or teaching and learning processes in his conclusion.

\section{CONCLUSION}

Through online learning, students can study as usual and will not miss lecture material, as well as more flexible time is: 1). Discusses some distance learning design recommendations by viewing teaching as a process of interaction between learning actors; 2). Interactions that are mediated by this technology need to be carefully designed and implemented concerning the needs of students; 3). Apart from what has been shared here, spaces of innovation are still very wide open in the design and implementation of distance learning; 4). Various effort was made to anticipate the state of the policy of learning and working from home (WFH); 5). Online lectures as one of the learning solutions in the COVID era spread, online lectures provide distance learning where lecture materials provided through technology tools will certainly make it easier for students to still get lectures without face to face. Likewise, the study room to continue to improve teaching. It is still this vast space of innovation and learning that frees educators to continue to observe, ask, try, find, and reflect on what forms of distance learning are most appropriate to the context of their students.

\section{Referensi}

Akcaoglu, M \& Lee, E. (2016). Increasing Social Presence in Online Learning Through Small Group Discussions. International Review of Research in Open and Distributed Learning. (17), (3). Aydin, I. E \& Gumus, S. (2016). Sense of Clasroom Community and Team Development Process In Online Learning. Turkish Online Journal of Distance Education (TOJDE), (17), (1), (5), 60-77.

Azizinezhad, M., \& Hashemi, M. (2011). The Use of Blogs in Teaching and Learning Translation. Procedia Social and Behavioral Sciences, 28, 867-

871. https://doi.org/10.1016/J.SBSPRO.2 011.11.159.

Cakir, H. (2013). Use of blogs in preservice teacher education to improve student engagement. Computers \& Education, 68, 244-252. https://doi.org/10.1016/J.COMPED U.2013.05.013 
Creswell, J. W. (2012). Educational Research: Planning, Conducting, and Evaluating Quantitative and Qualitative Research. London \& New York: Pearson Education.

Denoyelles, A., Zydney, J.M., Chen, B. (2014). Strategies for Creating A Community of Inquiry Through Online Asynchronous Discussions. MERLOT Journal of Online Learning and Teaching. 10, 1, 153165.

Garrison, D.R., Anderson, T., \& Archer, W. (2000). Critical Inquiry in a TextBased Environment: Computer Conferencing in Higher Education. The Internet and Higher Education, 2(2-3): 87- 105.

Garrison, D.R., Anderson, T., \& Archer, W. (2010). The First Decade of The Community of Inquiry Framework: A Retrospective. Internet and Higher Education , 13, 5-9.

Gheytasi, M., Azizifar, A., \& Gowhary, H. (2015). The Effect of Smartphone on the Reading Comprehension Proficiency of Iranian EFL Learners. Procedia - Social and Behavioral Sciences, 199, 225-230. https://doi.org/10.1016/J.SBSPRO.2 015.07.510

Gibbs, G. (1995). Assessing Student Centred Courses. Oxford: Oxford Centre for Staff Learning and Development.

Gunawardena, C.N. \& Zittle, F. (1997). Social Presence as A Predictor of Satisfaction Within A Computer Mediated Conferencing Environment. American Journal of Distance Education, 11, 3, 8-25.

Harto, K. (2018). TANTANGAN DOSEN PTKI DI ERA INDUSTRI 4.0. Jurnal Tatsqif, 16(1), 1-15. Retrieved from

http://journal.uinmataram.ac.id/index .php/tatsqif/article/view/159

Israel, S. E. (n.d.). Metacognition in Literacy Learning Theory, Assessment, Instruction and
Professional Development. Mahwah: Lawrence Erlbaum Associates, Inc.

Johnson, A. P. (2008). Teaching Reading and Writing a Guidebook for Tutoring and Remediating Students. (R. dan L. Education, Ed.). New York.

Jurnal Pendidikan Terbuka dan Jarak Jauh, Volume 19, Nomor 1, Maret 2018, 19-30 30 Hussein,

Keengwe, J., \& Georgina, D. (2012). The digital course training workshop for online learning and teaching. Education and Information Technologies, 17(4), 365-379. https://doi.org/10.1007/s10639-0119164-x Khabiri, M., \& Pakzad, M. (2012). The Effect of Teaching Critical Reading

Khusniyah, N., \& Hakim, L. (2019). EFEKTIVITAS PEMBELAJARAN BERBASIS DARING: SEBUAH BUKTI PADA PEMBELAJARAN BAHASA INGGRIS. Jurnal Tatsqif, 17(1), 19-33. https://doi.org/10.20414/jtq.v17i1.66 733 Strategies on EFL Learners' Vocabulary Retention. Journal of Teaching Language Skills, 31(1), 73-106.

https://doi.org/10.22099/JTLS.2012. 325

Kosasih, L., Iqbal, M. 2013. E-learning Dengan Menggunakan COI Framework. ComTEch (4), (2), 856866.

Kreijns, K., Acker, F.V., Vermeulen, M., Buuren, H.V. (2014). Community of Inquiry: Social Presence Revisited. E-learning and Digital Media, (11), (1), 5-18.

Kristanto, YD (2020), "Pendidikan yang Menggugah dan Menggairahkan di Tengah Covid-19", https://edukasi.kompas.com/read/20 20/05/02/120848771/pendidikanyang-menggugah-danmenggairahkan-di-tengah-covid19 ? page $=$ all. 
https://mediaindonesia.com/read/det ail/298964-covid-19-dan-

pembelajaran-daring

Martins, M. de L. (2015). How to Effectively Integrate Technology in the Foreign Language Classroom for Learning and Collaboration. Procedia - Social and Behavioral Sciences, 174, 77-84. https://doi.org/10.1016/J.SBSPRO.2 015.01.629

McGrath, L., Berggren, J., \& Mežek, Š. (2016). Reading EAP: Investigating high proficiency L2 university students' strategy use through reading blogs. Journal of English for Academic Purposes, 22, 152-164. https://doi.org/10.1016/J.JEAP.2016. 03.003

Nejad, B., \& Mahmoodi-Shahrebabaki, M. (2017, October 24). Effects of Metacognitive Strategy Instruction on the Reading Comprehension of English Language Learners Through Cognitive Academic Language Learning Approach (Calla). Retrieved from https://papers.ssrn.com/sol3/papers.c fm?abstract_id=3058349

Okan, Z., \& Taraf, H. U. (2013). The Use of Blogs in Second Language Teacher Education. Procedia - Social and Behavioral Sciences, 83, 282289.

https://doi.org/10.1016/J.SBSPRO.2 013.06.055

Özdemir, E., \& Aydın, S. (2015). The Effects of Blogging on EFL Writing Achievement. Procedia - Social and Behavioral Sciences, 199, 372-380. https://doi.org/10.1016/J.SBSPRO.2 015.07.521

Paris, S. G., \& Stahl, S. A. (2005). Children's Reading Comprehension and Assessment. New Jersey: Lawrence Erlbaum Associates, Inc.

Putrawangsa, S., \& Hasanah, U. (2018). INTEGRASI DIGITAL TEKNOLOGI DALAM
PEMBELAJARAN DI ERA INDUSTRI 4.0. Jurnal Tatsqif, 16(1), 42- 54. Retrieved from http://journal.uinmataram.ac.id/index .php/tatsqif/article/view/203

R. Aditiawarman, U., \& Mohamed, N. (2007). E-learning Acceptance In A Developing Country: A Case of The Indonesian Open University. Dipresentasikan dalam konferensi German e-Science, Baden, Germany, May2-4, 2007.

Rahman Sidek, E. A., \& Md.Yunus, M. (2012). Students' Experiences on using Blog as Learning Journals. Procedia - Social and Behavioral Sciences, 67, 135-143. https://doi.org/10.1016/J.SBSPRO.2 012.11 .314

Rovai, A.P. (2002). Development of An Instrument To Measure Classroom Community. The Internet and Higher Education, (5), 197-211.

Gardner, H., Johnson, C.W., Leach, G. and Vuylsteker, P. (2005). eScience Curricula at Two Australian Universities. In Proc. Seventh Australasian Computing Education Conference (ACE2005), Newcastle, Australia, Conferences in Research and Practice in Information Technology , 42. Young, A. and Tolhurst, D., Eds., ACS. pages 211216 (2005).

Scanlon, D. M., Anderson, K. L., \& Sweeney, J. M. (2010). Early Intervention for Reading Difficulties. New York: The Guilford Press.

Scollins-Mantha, B. (2008). Cultivating social presence in the online learning classroom: A literature review with recommendations for practice. International Journal of Instructional Technology and Distance Learning, 5(3), 1-15.

Short, J., Wiliams, E., \& Christie, B. (1976). The Social Psychology of Telecommunications. London: John Wiley \& Sons. 
Swan, K \& Shih, L. F. (2005). On The Nature and Development of Social Presence in Online Course Discussions. Journal or Asynchronous Learning Networks, 9(3), 115-136.

Tantri, N.R. (2018). How Far Do We Utilize The E-Learning Platform To Achieve 21st Century Skills in Teaching and Learning Process in School Context? A Conceptual Review. Diperesentasikan dalam English Teacher's Best Practices, Universitas Negeri Surabaya.

Wekke, I. S., \& Hamid, S. (2013). Technology on Language Teaching and Learning: A Research on Indonesian Pesantren. Procedia Social and Behavioral Sciences, 83, 585-589.

https://doi.org/10.1016/J.SBSPRO.2 013.06.111

Zydney, J.M. Denoyelles, A., \& Seo, K. (2012). Creating A Community of Inquiry in Online Environments: An Explorator Study on The Effect of Protocols on Interactions With Asynchronous Discussions. Computers \& Education, 58, 1, 7787. 